\title{
Insulin Immunogenicity in Pregnancy: Maternal and Fetal Studies
}

\author{
R. Mylvaganam ${ }^{1 *}$, J. M. Stowers ${ }^{2}$, J. M. Steel ${ }^{3}$, J. Wallace ${ }^{4}$, J.C. MacHendry ${ }^{4}$ and A. D. Wright ${ }^{5}$ \\ ${ }^{1}$ Immunology Unit, Department of Bacteriology of Aberdeen University, ${ }^{2}$ Diabetic Clinic, Royal Infirmary, Aberdeen, \\ ${ }^{3}$ Diabetic and Dietetic Department, Royal Infirmary, Edinburgh, ${ }^{4}$ Royal Maternity Hospital, Belfast and \\ ${ }^{5}$ The General Hospital, Birmingham, UK
}

\begin{abstract}
Summary. Antibodies to insulin were found in $92 \%$ of the 138 insulin-treated pregnant diabetic patients studied. No effect of pregnancy was shown on insulin antibody levels. Higher insulin antibody levels were significantly associated with the previous use of conventional insulins. Change from conventional to highly purified porcine insulin during pregnancy produced a significant reduction in insulin antibody levels. The combination of protamine zinc and soluble insulin used before pregnancy was found to be the most immunogenic. Insulin antibodies were freely transferred to the fetus but not de-
\end{abstract}

tectable after the first 8 months of life. No insulin antibodies were found in the cord blood or during the next few weeks in the infants of mothers who had no antibodies to their injected insulin. There was a tendency for higher insulin antibody levels to be associated with indices of neonatal morbidity but not with percentile birth weights and C-peptide levels in cord sera.

Key words: Diabetic pregnancy, insulin antibodies, insulin species and purity, infant mortality and morbidity, cord Cpeptide.
Insulin antibodies develop only in patients who have previously been treated with insulin $[1,2]$, apart from occasional reports of insulin autoantibodies which have been associated with hypoglycaemia [3,4]. On the other hand, administration of insulin antibodies is an established method of inducing transient experimental diabetes in some animals [5]. Insulin antibodies are mainly of the IgG class and may affect the response of blood glucose to insulin [6] and also local lipodystrophy at the sites of injection [7]. Insulin antibodies have been shown to cross the placenta $[8,9]$ and it is important to know if they bind fetal insulin and change its effectiveness. Potentially insulin-binding antibodies could neutralise some of the insulin produced by the fetus and thus stress the fetal pancreas to a degree greater than that attributable to hyperglycaemia alone [10-12]. Having crossed the placenta, insulin/insulin antibody complexes might form and produce Type III hypersensitivity reactions resulting in damage to organs such as lungs, kidneys and placenta [13]. Animal studies have shown that insulin antibodies can transfer insulin injected into the mother across the placenta to the fetus $[14,15]$ and this possibility has been investigated in only four patients [16]. Very little immunological research has been

* Present address - Division of Hematology, University of Miami, P.O. Box 016766, (R-36), Florida, USA undertaken in pregnant diabetic women in relation to insulin therapy $[8,16]$.

In this study our objectives were [1] to monitor insulin antibody levels during and after pregnancy; [2] to compare the immunogenicity of conventional and highly purified insulins and the difference in antibody levels after the change from conventional to highly purified insulin; [3] to study the transfer of maternal antibodies to the fetus and their persistence in the infant; and [4] to relate the levels of these antibodies to indices of neonatal morbidity, percentile birthweight and C-peptide values in cord sera.

\section{Patients and Methods}

\section{Patients}

The study included 128 pregnant Type 1 (insulin-dependent) diabetic patients and 10 gestational diabetic patients [17] who needed insulin to maintain blood glucose values within the normal range [18]. Of the 138 patients studied, 11 had abortions which consisted of two terminations, two blighted ova, one incompetent cervix, one maternal ketoacidosis and five spontaneous abortions. The remaining 127 , patients were sequentially studied for insulin antibodies during pregnancy and at about 6 weeks post partum. In this group, 36 were on conventional insulins and 82 on highly purified insulins throughout their pregnancies and nine patients were changed from conventional to highly purified insulin during the early part of pregnancy. The $138 \mathrm{pa}-$ 


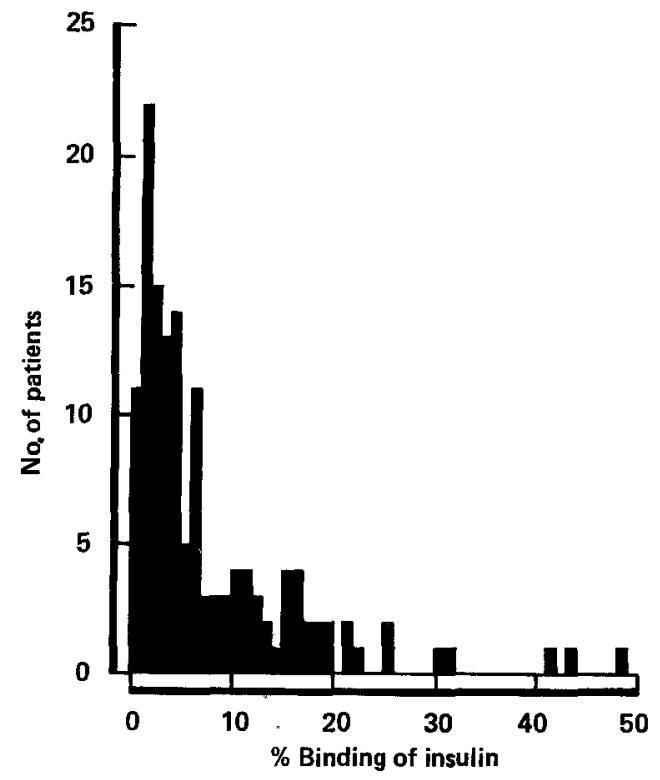

Fig. 1. Distribution of insulin-binding antibodies in insulin-treated pregnant diabetic patients

tients were drawn from Aberdeen (38), Edinburgh (35), Birmingham (24), Belfast (26) and a number of smaller units (15) in Scotland.

In the various centres, blood was collected at about 4 weekly intervals from the time of first attendance at antenatal clinics, at approximately 6 weeks after delivery and from the umbilical cord in 66 infants. The serum was separated and sent by first class mail to reach Aberdeen within $24 \mathrm{~h}$ where it was aliquoted and stored at $-20^{\circ} \mathrm{C}$ until assayed. Control studies showed that insulin antibody levels were stable at room temperature for at least $48 \mathrm{~h}$.

In 12 cases where insulin antibodies had been found in the cord blood, further blood samples were obtained from the infants at up to 9 months of age. Samples of maternal blood taken during labour were measured for glucose concentrations in each centre. Each cooperating centre was asked to complete a questionnaire of indices of morbidity of the babies, including APGAR score, assessment of respiratory difficulty, blood glucose, serum bilirubin, serum calcium, birthweight and maturity.

\section{Assay Procedure}

Highly purified beef insulin (Nordisk Insulin Laboratories, Copenhagen, Denmark) was iodinated by the chloramine-T method [19] using ${ }^{125} \mathrm{I}$ and stored in aliquots at $-20^{\circ} \mathrm{C}$ for a maximum period of 1 month.

Insulin antibodies were measured in the maternal and cord sera by the straight percentage binding method [20] which involved precipitating ${ }^{125} \mathrm{I}$-insulin/insulin antibody complexes with polyethylene glycol (mol. wt. 6,000). The measurements were done in triplicate and the results expressed as percentage binding of insulin minus the non-specific binding. This was determined by screening 64 sera from normal pregnancies, comprising 33 from the first trimester and 31 from the third trimester and 20 normal cord sera. The non-specific binding ranged from $0.5-1.0 \%$. The interassay coefficient of variation was $8.8 \%$ and the corresponding intra-assay coefficient was $<3.2 \%$.

C-peptide in cord sera was measured by radioimmunoassay [21] using the Daiichi C-peptide kit (Kabi Vitrum, London, UK). The sensitivity of the assay is $0.07 \mathrm{nmol} / 1$. Cord sera were first precipitated with $25 \% \mathrm{w} / \mathrm{v}$ aqueous polyethylene glycol solution chilled to $4{ }^{\circ} \mathrm{C}$ to remove insulin antibodies that would interfere with the assay [22] and $12.5 \%$ polyethylene glycol was added to the standard curve tubes. All cord sera were assayed in duplicate at one in two dilution. The values were expressed in nmol/ 1 after multiplying by the factor of 2 .

Bilirubin, calcium and glucose levels were measured in laboratories in each collaborating centre and the values were considered ab- normal or normal according to the reference standards of each laboratory.

\section{Criteria Used for Neonatal Morbidity}

Hypoglycaemia was defined as a value of $<1.8 \mu \mathrm{mol} / \mathrm{l}$ or in two cases as symptomatic hypoglycaemia at least $1 \frac{112}{h}$ after birth. Hypocalcaemia was defined as $<1.8 \mu \mathrm{mol} / 11-10$ days after birth. In babies born at term, hyperbilirubinaemia was defined as a level of $250 \mu \mathrm{mol} / 1$ or above at least $48 \mathrm{~h}$ after delivery or $150 \mu \mathrm{mol} / 1$ within $24 \mathrm{~h}$ of delivery. Serum bilirubin levels in premature babies were considered individually.

'Heavy-for-dates' and 'light-for-dates' babies were assessed according to the mixed pregnancy tables for percentile birthweights for gestation [23]. Respiratory difficulties included tachypnoea, retractions, grunting and cyanosis that appeared within the first $24 \mathrm{~h}$ of life.

Statistics were assessed by Student's t-test (paired and unpaired), Fisher's 'exact' test and correlation coefficient by the Spearman rank method where appropriate.

\section{Results}

\section{Insulin Antibodies in Insulin-treated Pregnant Diabetic Patients}

Of the 138 patients, 11 had no detectable insulin antibodies ( $=<1 \%$ binding). Figure 1 shows that the distribution of the patients with insulin antibodies is markedly skewed to the lower insulin antibody range (64.5\% of patients had $<10 \%$ binding). The majority of patients with insulin antibodies $(84.8 \%)$ was found within $0 \%-20 \%$ binding values.

\section{Changes in Insulin Antibody Levels During and After Pregnancy (Fig. 2)}

In order to determine if pregnancy affected insulin antibody levels, 28 patients were studied who had had no change in type of insulin treatment during and after pregnancy. The mean percentage binding of insulin calculated at intervals during and after pregnancy showed that there was no significant difference in insulin antibody levels during the course of pregnancy or after 6-14 weeks post partum.

\section{Insulin Antibodies in Relation to Change in Type of Insulin}

Insulin antibodies were followed in nine patients during pregnancy before and after their treatment was changed from conventional to highly purified insulin. In all cases, the insulin antibodies decreased in concentration at around 20 weeks after the changeover. The mean \pm SEM fall in percentage insulin binding was from $8.0 \pm 1.7$ to $3.7 \pm 1.1 \%(p<0.001)$.

\section{Previous Insulin Treatment and Insulin Antibodies}

Since our patients were drawn from several different centres, there was a considerable variety of insulin treatment. For the purpose of this analysis, we have grouped 


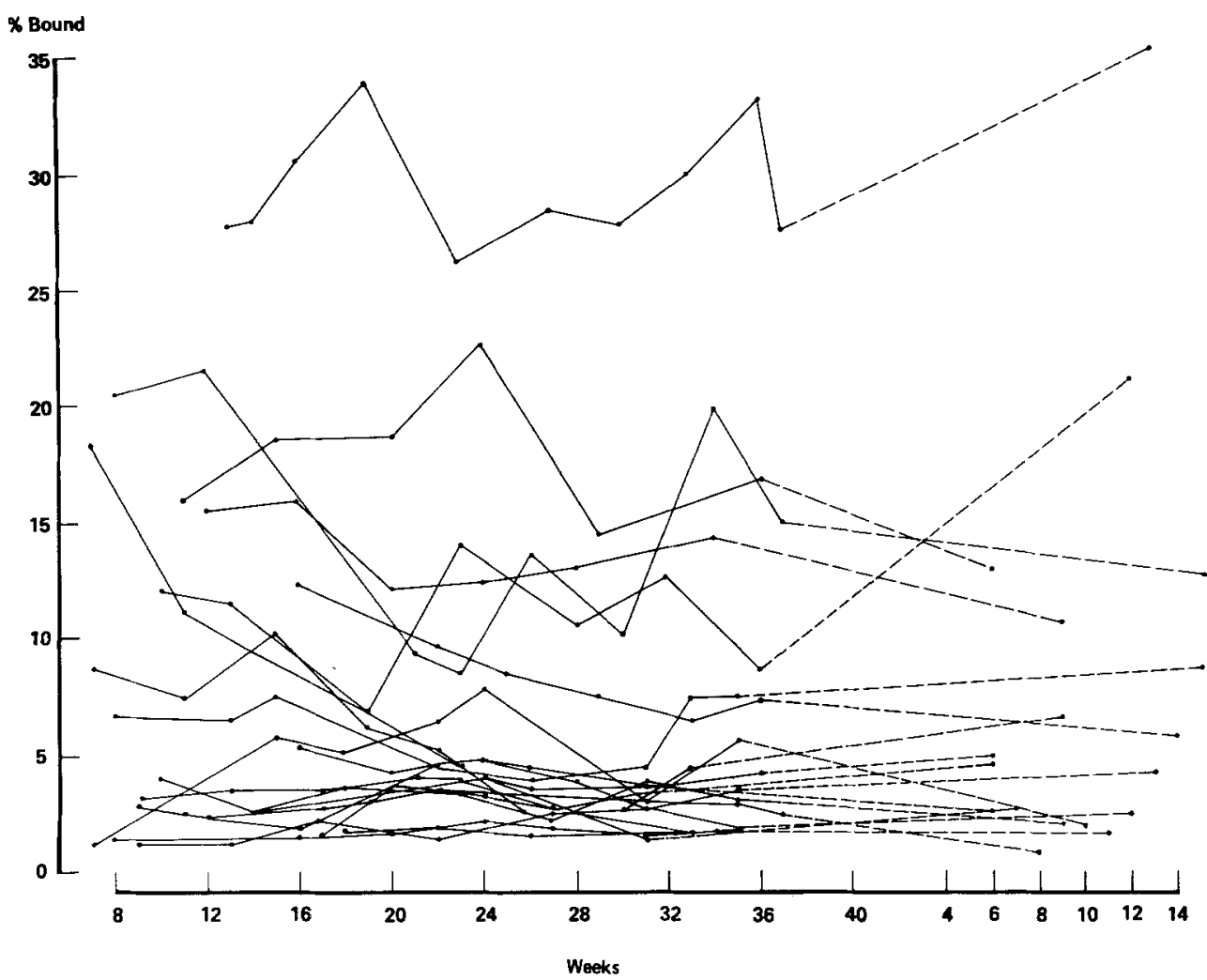

Fig. 2. Levels of insulin antibodies during pregnancy and 6-14 weeks post partum
Table 1. Insulin antibody levels in relation to type of insulin used before and during pregnancy

\begin{tabular}{|c|c|c|c|}
\hline \multicolumn{2}{|l|}{ Type of insulin treatment } & \multirow{2}{*}{$\begin{array}{l}\text { Mean of } \\
\text { highest } \% \\
\text { binding of } \\
\text { insulin } \\
\text { during } \\
\text { pregnancy }\end{array}$} & \multirow{2}{*}{$\begin{array}{l}\text { number of } \\
\text { patients }\end{array}$} \\
\hline $\begin{array}{l}\text { Before } \\
\text { pregnancy }\end{array}$ & $\begin{array}{l}\text { During } \\
\text { pregnancy }\end{array}$ & & \\
\hline $\begin{array}{l}\text { Conventional } \\
\text { Bovine }\end{array}$ & $\begin{array}{l}\text { Highly purified } \\
\text { Porcine }\end{array}$ & $10.6 \pm 10.4^{a}$ & 38 \\
\hline $\begin{array}{l}\text { Highly purified } \\
\text { Porcine } \\
\text { Bovine/Porcine }(3: 1) \\
\text { Bovine/Porcine }(3: 1) \\
\text { Porcine }\end{array}$ & $\begin{array}{l}\text { Highly purified } \\
\text { Porcine } \\
\text { Porcine } \\
\text { Bovine } \\
\text { Bovine }\end{array}$ & $\begin{array}{l}3.6 \pm 3.1^{b} \\
4.6 \\
4.7 \\
4.6\end{array}$ & $\begin{array}{r}32 \\
1 \\
1 \\
1\end{array}$ \\
\hline Conventional & Conventional & $9.0 \pm 8.8^{c}$ & 35 \\
\hline None & Conventional & 1.5 & 1 \\
\hline None & $\begin{array}{l}\text { Highly purified } \\
\text { Porcine } \\
\text { Bovine }\end{array}$ & $\begin{array}{r}1.2 \pm 0.5^{\mathrm{d}} \\
12.9 \pm 11.8^{\mathrm{e}}\end{array}$ & $\begin{array}{l}6 \\
3\end{array}$ \\
\hline
\end{tabular}

Results expressed as mean \pm SD

a,b $-\mathrm{F}=11.25, p<0.001 ; \quad \mathrm{b}, \mathrm{c}-\mathrm{F}=8.05, p<0.001 ; \quad \mathrm{b}, \mathrm{d}-\mathrm{F}=$ $38.40, p<0.001 ;$ b.e $-\mathrm{F}=14.49, p<0.001$

insulins into conventional and highly purified types. The conventional group included protamine zinc insulin, isophane, lente, semilente, ultralente, soluble, neutral soluble and biphasic. The highly purified group included the 'monocomponent' products of Novo, namely, Actrapid, Monotard, Ultratard, Semitard and Rapitard and also the rarely immunogenic insulins produced by Nordisk, namely Leo neutral (Velosulin), Leo retard (Insulatard), Mixtard (30/70) and Initard (50/50).

The results in Table 1 indicate that patients treated with conventional insulins before pregnancy maintain higher levels of insulin antibodies during pregnancy than patients treated with highly purified porcine insulin or who had no insulin before pregnancy. In patients who had not been treated with insulin before pregnancy, insulin antibody levels were found when bovine insulin was used during pregnancy, even when this was of 'monocomponent' type. Patients treated with highly purified porcine insulin before and during pregnancy developed more insulin antibodies than patients newly started on highly purified porcine insulin during pregnancy. (As the variances within these groups differed significantly, statistical comparisons of the means were not made). Generally there was a tendency for clinicians to change over to highly purified insulins during pregnancy - $69.5 \%$ compared with $30.5 \%$ before pregnancy.

\section{Conventional Insulins Before Pregnancy and Their Immunogenicities}

Table 2 shows that patients treated with conventional insulins before pregnancy had higher insulin antibody levels during pregnancy than patients treated with highly purified porcine insulins. In Table 2 the conventional insulins used before pregnancy have been separated into the various types and their immunogenicities recorded. Protamine zinc insulin with soluble insulin was 
Table 2. Immunogenicity of insulins used for treatment before pregnancy

\begin{tabular}{lcc}
\hline $\begin{array}{l}\text { Type of insulin treatment } \\
\text { before pregnancy }\end{array}$ & $\begin{array}{l}\text { Number of } \\
\text { patients }\end{array}$ & $\begin{array}{l}\text { Binding of } \\
\text { insulin (\%) }\end{array}$ \\
\hline Conventional & & \\
$\quad$ Unknown & 3 & $18.2 \pm 2.1$ \\
$\quad$ Protamine zinc insulin + soluble & 17 & $16.6 \pm 12.7^{\text {a }}$ \\
Soluble & 8 & $11.7 \pm 14.2$ \\
Soluble + semilente & 5 & $10.8 \pm 6.2$ \\
Lente + semilente & 11 & $7.0 \pm 5.9$ \\
Soluble + biphasic & 4 & $7.0 \pm 6.7$ \\
Soluble + isophane & 22 & $5.2 \pm 3.7$ \\
Isophane & 3 & $3.3 \pm 0.9$ \\
Highly purified & & \\
$\quad$ Leo neutral + Leo retard & 15 & $4.2 \pm 2.9$ \\
$\quad$ Actrapid, monotard or semitard & 18 & $3.4 \pm 3.3$ \\
$\quad$ Rapitard & 2 & 4.7 \\
\hline
\end{tabular}

Results expressed as mean $\pm \mathrm{SD}$

a The difference in the mean percentage binding of insulin with PZI + soluble and that of all the other conventional insulins is highly significant $(p<0.001, t=4.79)$

Table 3. Persistence of insulin antibody levels in infants

\begin{tabular}{|c|c|c|c|}
\hline $\begin{array}{l}\text { Infant } \\
\text { Number }\end{array}$ & $\begin{array}{l}\text { Insulin } \\
\text { binding (\%) }\end{array}$ & $\begin{array}{l}\text { Decrease in } \\
\text { insulin antibodies } \\
\text { from time of } \\
\text { birth in infants' } \\
\text { serum }^{\mathrm{a}}(\%)\end{array}$ & $\begin{array}{l}\text { Age of } \\
\text { infant at } \\
\text { measurement } \\
\text { (weeks) }\end{array}$ \\
\hline 1 & 2.8 & 46 & 4 \\
\hline 2 & 23.7 & 67 & 7 \\
\hline 3 & 2.4 & 46 & 7 \\
\hline 4 & 1.9 & 58 & 8 \\
\hline 5 & 1.4 & 33 & 8 \\
\hline 6 & 2.9 & 66 & 10 \\
\hline 7 & 10.5 & 83 & 10 \\
\hline 8 & 1.4 & 71 & 12 \\
\hline 9 & 1.4 & 57 & 12 \\
\hline 10 & 20.6 & 81 & 16 \\
\hline 11 & 10.8 & 91 & 32 \\
\hline 12 & 2.3 & 70 & 34 \\
\hline
\end{tabular}

a $t=2.8910$, Spearman's rank correlation coefficient, $\mathrm{R}=0.674$, $p<0.02$

Table 4. Features of infant morbidity in relation to maternal insulin antibody levels

\begin{tabular}{lrrl}
\hline $\begin{array}{l}\text { Features of infant morbidity } \\
\text { in 118 infants }\end{array}$ & $\begin{array}{l}\text { Infant } \\
\text { population } \\
\text { affected }\end{array}$ & $\begin{array}{l}\text { Binding } \\
\text { of insulin } \\
(\%)\end{array}$ \\
\cline { 2 - 3 } & \multicolumn{2}{l}{ Number \% } & \\
\hline Hypoglycaemia & 32 & 27.1 & $8.0 \pm 9.6$ \\
Hyperbilirubinaemia & 22 & 18.6 & $8.3 \pm 10.3$ \\
Respiratory difficulty & 21 & 17.8 & $9.8 \pm 11.0$ \\
Hypocalcaemia & 14 & 11.9 & $7.5 \pm 11.2$ \\
Congenital malformations (minor) & 4 & 3.4 & $6.9 \pm 7.6$ \\
None & 41 & 34.9 & $6.7 \pm 5.6$ \\
\hline
\end{tabular}

Results expressed as mean $\pm \mathrm{SD}$

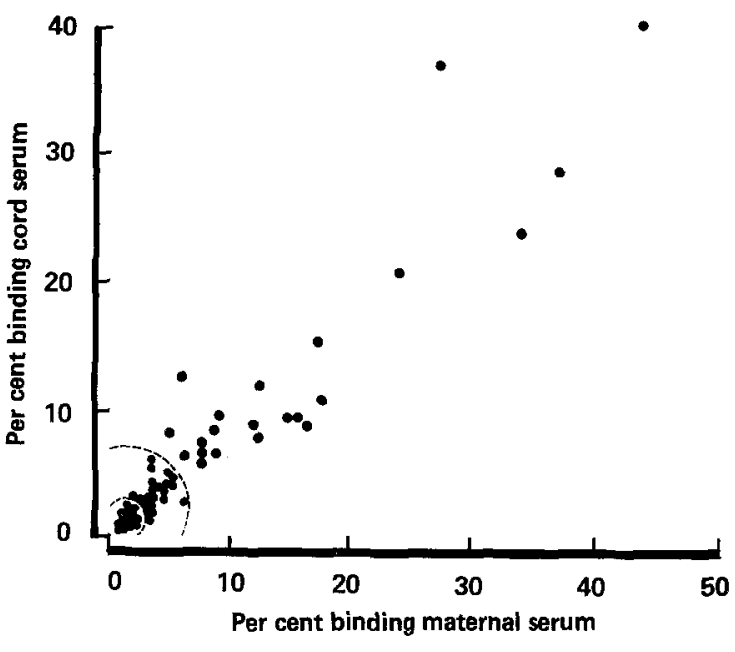

Fig.3. Comparison of insulin antibody levels in maternal and cord sera

the combination found to be the most immunogenic when compared with the other conventional insulins. $(p<0.001)$ No difference in immunogenicity was noted between the various highly purified porcine insulins.

\section{Transfer of Maternal Insulin Antibodies}

In six of the 66 cord sera, no insulin antibodies were detectable. In cases where the mothers had no insulin antibodies none was found in the cord blood. Figure 3 shows a good correlation of the level of insulin antibody levels between mother and infant at the time of delivery $(r=0.946)$, and this must indicate a ready transfer of maternal antibodies across the placenta.

\section{Persistence of Maternal Antibodies in the Progeny}

The insulin antibodies that were transferred from the mother to the fetus during pregnancy decreased in concentration in all 12 infants that were studied for up to 34 weeks after birth (Table 3). In cases where the insulin antibody levels were very low at delivery they disappeared sooner than in cases with high levels at delivery.

\section{Insulin Antibodies and Infant Mortality}

In assessing the progeny there were five twin pregnancies whose infants were excluded from this study because of their increased perinatal risk. There were also 11 abortions and four perinatal deaths. Table 4 relates five indices of infant morbidity to the mean percentage insulin binding in the mother's serum. In each case the mean percentage binding was greater than that in the serum of mothers whose infants had none of these indices of morbidity, normal APGAR scores and weights 


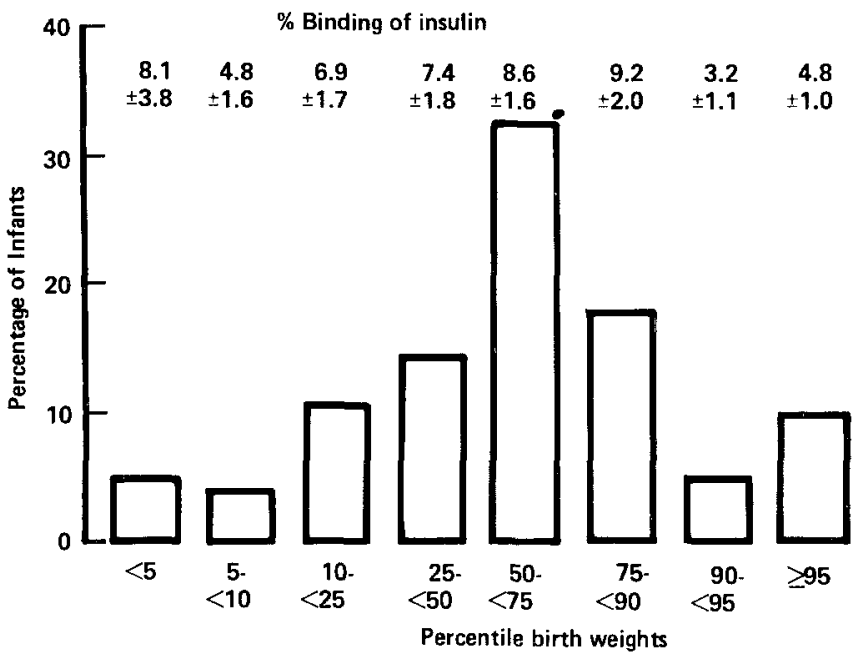

Fig. 4. Association between insulin antibody levels ( \pm SEM) and percentile birth weights of infants of insulin-treated diabetic mothers

within the tenth to ninetieth centile range. Nevertheless, the difference was not statistically significant, bearing in mind the skew distribution of insulin binding results (Fig. 1).

Of the 11 abortions, six could be explained by well recognised causes, as already mentioned. The remaining five spontaneous abortions (mean percentage binding $9.9 \pm 12.5 \%$ ), four perinatal deaths $(11.3 \pm 10.4 \%)$ and three major congenital malformations $(16.2 \pm 8.0 \%)$ were not significantly correlated with higher insulin antibody levels, using the unpaired Student's t-test.

\section{Insulin Antibodies and Percentile Birthweights}

Figure 4 shows the distribution of percentile birthweights of 122 infants of insulin-treated diabetic mothers and of the corresponding average maternal insulin antibody levels. About the expected proportion (actually $76.2 \%$ ) was placed between the tenth and ninetieth percentiles. Only $9.0 \%$ were below the tenth percentile and $14.8 \%$ above the ninetieth percentile. No significant association was found between percentile birthweight and insulin antibody levels.

\section{Insulin Antibodies and C-peptide Levels}

The association between insulin antibody levels and Cpeptide values was determined in cord sera of 37 infants after the insulin antibodies were removed with polyethylene glycol. The mean \pm SD percentage binding of insulin was $6.7 \pm 8.0 \%$ and mean C-peptide concentration was $0.33 \pm 0.37 \mathrm{nmol} / 1$. The average blood glucose value of the mothers at or near delivery was $7.1 \pm$ $2.1 \mu \mathrm{mol} / \mathrm{l}$ (mean $\pm \mathrm{SD}$ ) and within this range did not correlate with C-peptide concentrations in the cord sera $(r=0.2969)$. The mean \pm SD C-peptide value of normal infants was $0.27 \pm 0.13 \mathrm{nmol} / 1$. There was no statistically significant correlation between levels of insulin antibodies and C-peptide in cord sera $(r=0.3130)$.

\section{Discussion}

The main reason for starting this study was the known fact that insulin antibodies are mainly of the IgG class $[24,25]$ and can be easily transferred across the placenta from the mother to the fetus [8]. It is also known that insulin antibodies can neutralise or delay some of the physiological effects of insulin [6] and this therefore may be important for the metabolism of the fetus in pregnancy [12]. It has been suggested that there is a general immunosuppression in pregnancy enabling the fetus to survive as an allograft [26]. Our sequential measurements of insulin antibody levels (a measure of humoral immunity) during and after pregnancy in patients on the same type of insulin showed no significant change in contrast to those of other workers $[8,16,27]$ who did not specify the type of conventional insulin treatment during and after pregnancy. In our experience, changing patients from one conventional insulin type to another leads to change in insulin antibody levels, particularly from protamine zinc and soluble insulin to conventional isophane and soluble. Therefore pregnancy was not found to suppress humoral immunity, although there is evidence that it does suppress the cellular immune response [28]. When patients were changed from conventional to highly purified insulin during pregnancy there was a slow reduction in insulin antibody levels. In all cases the changeover was to highly purified porcine insulin. These results agree with those of studies on non-pregnant diabetic patients $[20,24,29,31]$. Furthermore, very low levels of insulin antibodies have been reported in newly diagnosed diabetic patients treated with highly purified porcine insulin $[32,33]$. Our results have shown that it is necessary not only to use highly purified but also porcine, rather than bovine insulin, if insulin antibody formation is to be minimised. We have in addition shown that insulin antibody levels in pregnancy are more related to the type of insulin used before the pregnancy than during it. The insulin treatment before pregnancy was followed as far back as 1975 to include those who were changed from conventional to highly purified insulin when it first became available. Conventional insulin therapy before pregnancy was significantly associated with higher insulin antibody levels during pregnancy. Protamine zinc insulin (PZI) with soluble insulin was found to be the most immunogenic combination. The protamine is unlikely to contribute towards the immunogenicity because its occurrence in highly purified porcine insulin (Leo retard or Insulatard) is not significantly immunogenic. It is possible that the combination of an acidic insulin (soluble) with a particulate insulin (PZI) may enhance the immunogenicity [32]. 
Our fetal studies on 138 pregnancies have confirmed earlier work indicating that insulin antibodies cross the human placenta. We have no evidence that antibodies to insulin are maintained in the infant's circulation since the levels fall off after birth, as would be expected if they were passively transferred from the mother. The persistence of such antibodies depends on the initial concentration in the cord serum.

If passively acquired insulin antibodies neutralised some of the fetal insulin leading to increased insulin production, then a correlation would be expected between cord insulin antibody levels and cord C-peptide or insulin as has been claimed by some investigators $[10$, 12]. In our preliminary study [34] C-peptide was measured by a radioimmunoassay [35] after removing the insulin antibodies bound to proinsulin which crossreact with C-peptide antibody [22] and precipitating the ${ }^{125}$ I-C-peptide - C-peptide antibody complex with a second antibody instead of ethanol. In 18 cord sera studied at that time, we found no correlation between levels of C-peptide and insulin antibodies. In our present study, we used a different radioimmunoassay kit [21] employing the same technique as that just described and again found no correlation in the 37 cord samples that were tested.

If maternal antibodies to insulin were a factor in the production of hyperinsulinism in the fetus an effect might be expected on the rate of growth and fat formation, as has been shown clearly for maternal hyperglycaemia [36]. Our results fail to show any association between levels of insulin antibody and centile weight distribution (Fig.4).

On considering clinically more significant events the five spontaneous abortions could not be shown to be significantly related to the levels of insulin antibody. Similarly the four perinatal deaths and three major and four minor congenital malformations were too few to be able to demonstrate any significant association with insulin antibody levels. More sensitive indices should be the criteria of infant morbidity, namely hypoglycaemia, hypocalcaemia, respiratory distress and hyperbilirubinaemia. There was a high prevalence of such features and each one considered separately was associated with higher mean percentage insulin binding in the mother than was found in the mothers of the unaffected babies. Nevertheless, the standard deviations of the binding results were large so that they can do no more than suggest that the insulin antibodies which were transferred freely to the fetus may have caused harm before and after birth. The possibility of long term effects in the infants has still to be investigated. In our study, it is worth noting that insulin antibody levels were nearly all in the low range and it is possible that we were looking mainly at patients with antibodies below a dangerous level.

Acknowledgements. R.M. and the immunology studies were supported by Nordisk-UK. Suitable patients were kindly provided by Drs.
G. M. Hill and A.W.M.Smith, Kirkaldy, Dr. N.Patel, Dundee, Drs. M. Geale and R. B. Wilson, Dumfries and Dr. W. G. Millar, Perth. Dr. H. W. Sutherland, Aberdeen and Professor J.M. G. Harley, Belfast, are thanked for their support on the obstetric side. Immunological expertise was kindly supplied by Dr. A. B. Kurtz, Middlesex Hospital, London and Dr. J. B. Solomon, Immunology Unit, Department of Bacteriology, University of Aberdeen.

\section{References}

1. Berson SA, Yalow RS, Baumann A, Rothschild MA, Newerly K (1956) Insulin-1 ${ }^{131}$ metabolism in human subjects; demonstration of insulin-binding globulin in the circulation of insulin treated subjects. J Clin Invest 35: 170-190

2. Skom JH, Talmage DW (1958) Non-precipitating insulin antibodies in diabetes. $\mathrm{J}$ Clin Invest 37: 787-793

3. Hirata Y, Tominaga M, Ito JI, Noguchi A (1974). Spontaneous hypoglycaemia with insulin autoimmunity in Graves' disease. Ann Intern Med 81: 214-218

4. Goldman J, Baldwin D, Rubinstein AH, Klink DD, Blackard WG, Fisher LK, Roe TF, Schnure JJ (1979) Characterization of circulating insulin and proinsulin-binding antibodies in autoimmune hypoglycaemia. J Clin Invest 63: 1050-1059

5. Wright PH (1961) The production of experimental diabetes by insulin antibodies. Am J Med 31: 892-900

6. Dixon K, Exon PD, Hughes HR (1972) Insulin antibodies in aetiology of labile diabetes. Lancet 1:343-347.

7. Reeves WG, Allen BR, Tattersall RB (1980). Insulin-induced lipoatrophy: evidence for an immune pathogenesis. Br Med J 2: $1500-1503$

8. Spellacy WN, Goetz FC (1963) Insulin antibodies in pregnancy Lancet 2: 222-224

9. Jorgensen KR, Deckert T, Pedersen LM, Pedersen J (1966) Insulin antibody and glucose in plasma of newborn infants of diabetic women. Acta Endocrinol (Copenh) 52: 154-167

10. Martin FIR, Dahlenburg GW, Russell J, Jeffrey P (1975) Neonatal hypoglycaemia in infants of insulin-dependent diabetic mothers. Arch Dis Child 50:472-476

11. Falluca F, Pachi A, Gerlini G, Giangrande L, Scarciotta O, Pedulla C, Pintor A, Iavicol M (1980) Placental transfer of IgG insulin antibodies and metabolic and clinical complications in the IDMs. Diabetologia 19: 273 (Abstract)

12. Heding LG, Persson B, Strangenberg M (1980) B-cell function in newborn infants of diabetic mothers. Diabetologia 19: 427-432

13. Tamas GY, Bekefi $D$, Gaal O (1975) Insulin antibodies in diabetic pregnancy. Lancet 1: 521 (Letter)

14. Thorell JI (1966) Placental transfer of insulin - ${ }^{131}$ I in guinea pigs immunized against insulin. Acta Endocrinol (Copenh) 52: 276-291

15. Mylvaganam R, Solomon JB (1980) Transfer of ${ }^{125} \mathrm{I}$-insulin in immunized pregnant guinea pigs. In: Solomon JB (ed) Aspects of developmental and comparative immunology I. Pergamon, Oxford, pp 341-346

16. Kalhan SC, Schwartz R, Adam PAJ (1975) Placental barrier to human insulin - $\pm{ }^{125} \mathrm{I}$ in insulin-dependent diabetic mothers. J Clin Endocrinol Metab 40: 139-142

17. National Diabetes Data Group (1979) Classification and diagnosis of diabetes mellitus and other categories of glucose intolerance. Diabetes 28: 1039-1057

18. Victor A (1979) Normal blood sugar variation during pregnancy. Acta Obstet Gynecol Scand 53:37-40

19. Greenwood FC, Hunter WM, Glover TS (1963) The preparation of I- ${ }^{131}$ labelled human growth hormone of high specific radioactivity. Biochem J 89: 114-123

20. Kurtz AB, Matthews IA, Mustaffa BE, Daggett PR, Nabarro IDN (1980) Decrease of antibodies to insulin, proinsulin and contaminating hormone after changing treatment from conventional beef to purified pork insulin. Diabetologia 18: 147-150

21. Kaneko T, Oka H, Munemura M, Oda T, Yamashita K, Suzuki S, 
Yanaihara N, Hashimoto T, Yanaihara C (1974) Radioimmunoassay of human proinsulin $\mathrm{C}$-peptide using synthetic human connecting peptide. Endocrinol Jpn 21: 141-145

22. Kuzuya H, Blix PM, Horwitz DL, Steiner DF, Rubinstein AH (1977) Determination of free and total insulin and C-peptide in insulin-treated diabetics. Diabetes 26: 22-29

23. Thomson AM, Billewicz WZ, Hytten FE (1968) The assessment of fetal growth. J Obstet Gynaec Brit Cwlth 75: 903-916.

24. Faulk WP, Karam JH, Fudenberg HH (1971) Human anti-insulin antibodies. J Immunol 106: 112-116

25. Christiansen Aa H (1973) Radioimmunoelectrophoresis in the determination of insulin binding to IgG. Methodological studies. Horm Metab Res 5: 147-154.

26. Medawar PB (1954) Some immunological and endocrinological patterns raised by the evolution of viviparity in vertebrates. Symp Soc Exp Biol 7: 320-328

27. Exon PD, Dixon K, Malins JM (1974) Insulin antibodies in diabetic pregnancy. Lancet 2:126-128

28. Davis JC, Finn R, Hipkin LJ, Hill CA (1978) Do plasma glycoproteins induce lymphocyte hyporesponsiveness and insulin resistance? Lancet 2: 1343-1345

29. Andreani D, Iavicoli M, Tamburrano G, Menzinger G (1974) Comparative trials with monocomponent (MC) and monospecies (MS) pork insulins in the treatment of diabetes mellitus. Influence of antibody levels on insulin requirement and some complications. Horm Metab Res 6: 447-454

30. Mustaffa BE, Daggett PR, Nabarro JDN (1977) Insulin binding capacity in patients changed from conventional to highly purified insulins. An indicator of likely response. Diabetologia 13: 311-315

31. Bruni B, Gamba S, Regis G, Turco GL (1978) Proinsulin and acomponent antibodies in diabetics after long-term monocomponent insulin treatment. Diabetologia 14: 165-169

32. Ortved Anderson O (1975) The immunogenic properties of highly purified insulin preparations. The clinical importance of insulinbinding antibodies. Acta Endocrinol (Copenh) 78: 723-735

33. Graber D, Fankhauser S (1978) Die antigenität einiger neuer chromatographisch gereinigter Depot-Insulin-Präparate Schweiz Med Wochenschr 108: 1807-1809

34. Mylvaganam R, Stowers JM, Bottazzo GF, Steel JM, Boyle DD, Wright AD, Fisher PM (1980) Antibodies to insulin and islet cells in diabetic pregnancy. Diabetologia 19: 562 (Abstract)

35. Heding LG (1975) Radioimmunological determination of human C-peptide in serum. Diabetologia 11: 541-548

36. Pedersen J (1977) Hyperglycaemia - hyperinsulinism therapy and birth weight. In: The pregnant diabetic and her newborn, 2 nd edn. Munksgaard, Copenhagen, pp 211-217

Received: 1 June 1981

and in revised form: 21 August 1982

Professor J. M. Stowers

Diabetic Clinic

Royal Infirmary

Woolmanhill, Aberdeen AB9 1GS

Scotland, UK 